\title{
Detection of Carriers of Benign X-Linked Muscular Dystrophy
}

\author{
ALAN E. H. EMERY,* M.D., M.SC., PH.D., M.R.C.P.ED. ; ENID R. CLACK†; SYBIL SIMON, $\ddagger$ M.B. \\ JOHN L. TAYLOR,§ M.B., B.SC., M.R.C.P.
}

Brit. med. F., 1967, 4, 522-523

From the point of view of genetic counselling carrier detection is most important in X-linked disorders. Okinaka et al. (1959) were the first to employ the serum level of creatine kinase to detect female carriers of X-linked Duchenne muscular dystrophy. Since then many investigators have confirmed the usefulness and reliability of this test. So far results on over 200 carriers have been reported, and of these approximately two-thirds were found to have significantly raised levels of serum creatine kinase (Emery, 1967).

Besides the severe Duchenne type of muscular dystrophy, another X-linked form of muscular dystrophy has been recognized by Becker (1955, 1957, 1962). This type of muscular dystrophy is clinically similar to Duchenne muscular dystrophy in that weakness begins in the pelvic girdle musculature, only later affecting the upper limbs, and there is pseudohypertrophy of the calf muscles. However, it differs from Duchenne muscular dystrophy because the disease does not manifest itself until the teens or early twenties, and affected individuals usually become chair-ridden only after 25 to 30 years. This report is concerned with the usefulness of serum enzyme studies for detecting carriers of this benign Becker type X-linked muscular dystrophy.

\section{Subjects and Methods}

Carriers.-All the carriers belonged to four large families, in each of which were several affected males. A definite carrier has been defined as a daughter of an affected man or a woman with an affected son and a family history of other male relatives having been similarly affected-for example, a brother or maternal uncle.

Controls.-Enzyme determinations were carried out on 50 normal women with no history of any neuromuscular disease and of comparable age to the carriers.

Methods.-Blood samples were taken during everyday activity. In most cases enzyme determinations were carried out within an hour or so of the blood sample being taken. In the few instances where this was not possible the serum was frozen and kept at $-20^{\circ} \mathrm{C}$. until the following day. No specimens were stored for more than 24 hours. Serum levels of creatine kinase were estimated according to the method of Tanzer and Gilvarg (1959), using a Hilger and Watts Uvispek spectrophotometer with temperature control. Cysteine was incorporated in the reaction mixture to a final concentration of $1 \mu \mathrm{M} / \mathrm{ml}$. The incorporation of cysteine has been shown to increase the accuracy and reproducibility of assay methods for serum creatine kinase and to prevent the loss of enzyme activity which occurs when serum is stored (Hughes, 1962 ; Okinaka et al., 1964 ; Kar and Pearson, 1965; Finley and Anderson, 1966). With cysteine incorporated in the reaction mixture the values obtained were not appreciably affected by storing serum samples for

* Reader, University Department of Medical Genetics, Manchester Royal

† Field Worker, University Department of Medical Genetics, Manchester Royal Infirmary.

₹ Research Fellow, University Department of Medical Genetics, Manchester Royal Infirmary.

$\checkmark$ Consultant Physician, the Infirmary, Rochdale, Lancs. several days at $-20^{\circ} \mathrm{C}$. However, without cysteine the values obtained after storage were significantly less than those obtained with fresh serum. It would seem, therefore, that if stored serum is used cysteine should be incorporated in the reaction mixture.

Results are expressed in international units, one unit being that amount of enzyme which catalyses the transformation of $1 \mu \mathrm{M}$ of creatine per $1,000 \mathrm{ml}$. of serum per minute at $25^{\circ} \mathrm{C}$. and $p \mathrm{H}$ 9. Duplicate determinations were carried out on each sample of serum.

\section{Results}

The values for the serum levels of creatine kinase in the controls were not normally distributed, but the cumulative

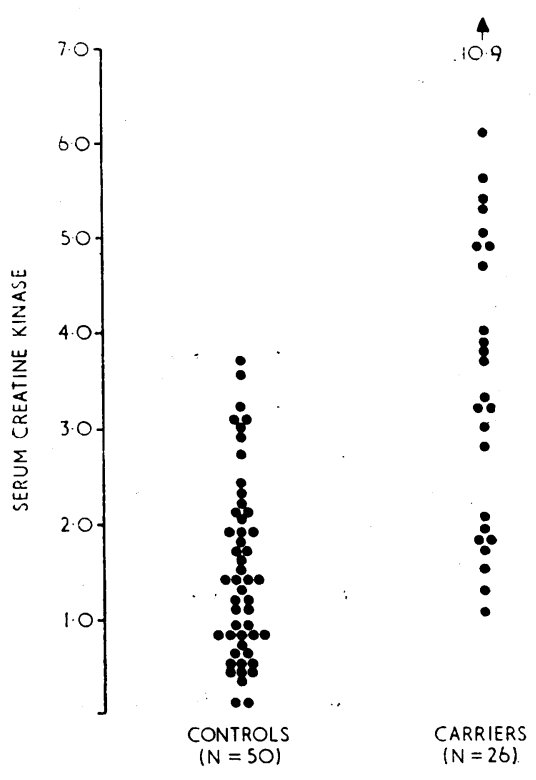

Fig. 1.-Serum creatine kinase levels in controls and carriers, actual values.

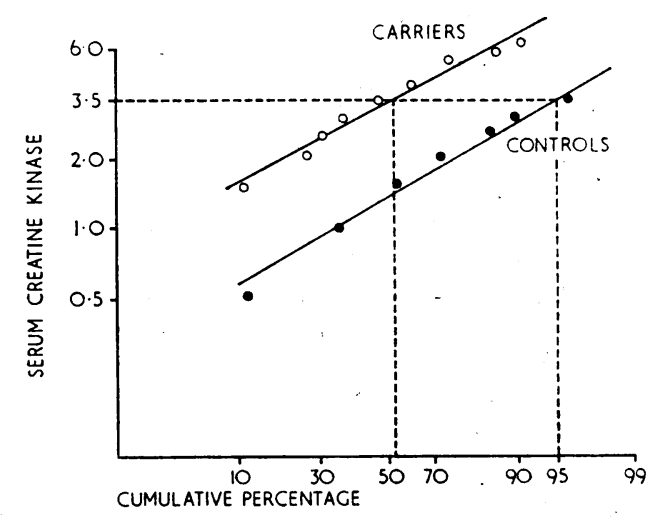

Fig. 2.-Serum creatine kinase levels in controls and carriers, cumulative percentage frequency of the logarithms of the values. 
distribution produced a close approximation to a straight line on a log. probability plot, and from this curve the normal 95 percentile was estimated to 3.5 units. Of the 26 definite carriers who have been tested $13(50 \%)$ had serum levels of creatine kinase which exceeded the normal 95 percentile (Fig. 1). From the cumulative log. probability plot approximately $48 \%$ of carriers would be predicted to have values more than 3.5 units (Fig. 2). There was no significant correlation $(r=+0.04)$ between age and the serum level of creatine kinase.

Enzyme determinations were carried out on 14 possible carriers. These were women who were sisters of affected males, sisters of definite carriers, or daughters of definite carriers. Except for two boys who were not available for testing, all the sons of these possible carriers were examined and their serum level of creatine kinase was determined, but none was found to be affected. Five $(36 \%)$ of these possible carriers had raised serum creatine kinase levels.

None of the 26 definite carriers or any of the 14 possible carriers had enlarged calves or any evidence of muscle weakness.

\section{Discussion}

A benign form of X-linked muscular dystrophy was first recognized by Becker (1955, 1957, 1962). Other investigators have also reported families in which the onset was later and the progression slower than in the classical X-linked Duchenne

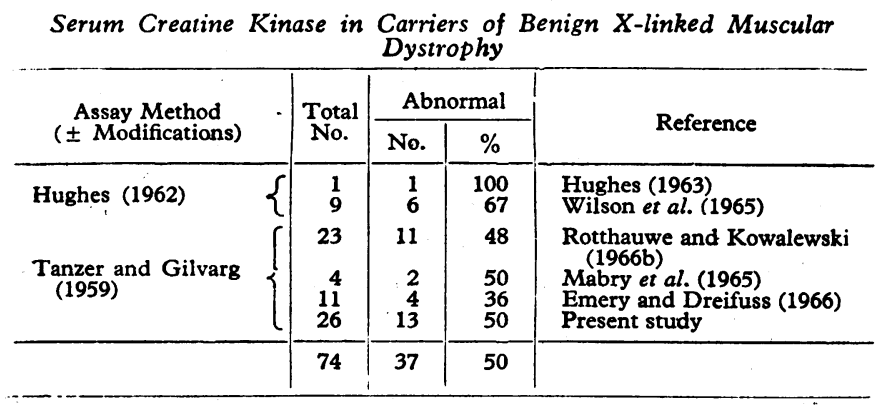

type of muscular dystrophy (Levison, 1951; Lamy and de Grouchy, 1954 ; Walton, 1955-6, 1956-7 ; Blyth and Pugh, 1958-9 ; Emery, 1964 ; Rotthauwe and Kowalewski, 1966a). Mabry et al. (1965) and Emery and Dreifuss (1966) have described families with benign forms of X-linked muscular dystrophy which appeared to differ clinically from the Becker type, and these investigators have suggested that there may be at least three different types of benign $\mathrm{X}$-linked muscular dystrophy.

So far there have been few published reports of serum enzyme studies in carriers of benign $\mathrm{X}$-linked muscular dys- trophy (see Table). The findings of the present study are in good agreement with those of Rotthauwe and Kowalewski (1966b) in showing that approximately $50 \%$ of carriers have significantly elevated levels of creatine kinase. The test may therefore be useful in genetic counselling in this form of muscular dystrophy.

\section{Summary}

The serum level of creatine kinase has been found to be significantly elevated in 13 out of $26(50 \%)$ definite carriers and 5 out of $14(36 \%)$ possible carriers of benign (Becker type) $\mathrm{X}$-linked muscular dystrophy. The test may therefore be useful in genetic counselling in this form of muscular dystrophy.

Grateful thanks are due to Dr. J. Timson and Dr. D. GardnerMedwin for valuable help in tracing members of certain families and to Miss Valerie Hodson for technical assistance. The work was supported by a research grant from the Muscular Dystrophy Group of Great Britain. S. S. was in receipt of an M.R.C. researcb scholarship.

\section{REFERENCES}

Becker, P. E. (1955). Dtsch. Z. Nervenheilk., 173, 482.

- (1957). Acta genet. (Basel), 7, 303. (1962). Rev. canad. Biol., 21, 551.

Blyth, H., and Pugh, R. J. (1958-9). Ann. hum. Genet., 23, 127. Emery, A. E. H. (1964). Clin. Orthop., No. 33, p. 164.

- (1967). In Exploratory Concepts in Muscular Dystrophy and Related Disorders, edited by A. T. Milhorat and W. K. Engel. In press.

— and Dreifuss, F. E. (1966). F. Neurol. Neurosurg. Psychiat., 29, 338.

Finley, P. R., and Anderson, F. (1966). In Proceedings of VI International Congress on Clinical Chemistry, Munich, p. 183. Basel.

Hughes, B. P. (1962). Clin. chim. Acta, 7, 597.

- (1963). In Proceedings of Second Symposium on Current Research in Muscular Dystrophy, p. 167. London.

Kar, N. C., and Pearson, C. M. (1965). Proc. Soc. exp. Biol. (N.Y.), 118,662 .

Lamy; M., and de Grouchy, J. (1954). f. Génét. Hum., 3, 219.

Levison, H. (1951). Acta psychiat. Neurol., Suppl. No. 76, p. 1.

Mabry, C. C., Roeckel, I. E., Munich, R. L., and Robertson, D. (1965). New Engl. F. Med., 273, 1062.

Okinaka, S., et al. (1959). 84th Annual Meeting of American Neurological Associations, Atlantic City.

_ et al. (1964). F. Lab. clin. Med., 64, 299.

Rotthauwe, H. W., and Kowalewski, S. (1966a). Humangenetik, 3, 17.

- (1966b). Ibid., 3, 30.

Tanzer, M. L., and Gilvarg, C. (1959). F. biol. Chem., 234, 3201.

Walton, J. N. (1955-6). Ann. hum. Genet., 20, 1.

(1956-7)... Ibid., 21, 40.

Wilson, K. M., Evans, K. A., and Carter, C. O. (1965). Brit. med. J., 1. 750 . 